\title{
Short Communication: \\ Cremanthodium indica (Asteraceae, Senecioneae), a new species from the Eastern Himalaya, India
}

\author{
DIPANKAR BORAH ${ }^{1}$, RAJEEV KUMAR SINGH ${ }^{2, \boldsymbol{v}}$, LOBSANG TASHI THUNGON ${ }^{3}$ \\ ${ }^{1}$ Department of Botany, Goalpara College. Goalpara 783101, Assam, India. "email: rksbsiadsingh@ gmail.com \\ ${ }^{2}$ Botanical Survey of India, Southern Regional Centre. TNAU Campus, Lawley Road, Coimbatore 641003, Tamil Nadu, India \\ ${ }^{3}$ Department of Forestry, North Eastern Regional Institute of Science and Technology. Nirjuli 791109, Arunachal Pradesh, India
}

Manuscript received: 2 February 2020. Revision accepted: 12 February 2021.

\begin{abstract}
Borah D, Singh RK, Thungon LT. 2021. Short Communication: Cremanthodium indica (Asteraceae, Senecioneae), a new species from the Eastern Himalaya, India. Biodiversitas 22: 1272-1276. Cremanthodium indica D.Borah, R.Kr. Singh \& Thungon (Asteraceae, Senecioneae), a new species from Eastern Himalayan state Arunachal Pradesh, India is described and illustrated. The new species is allied to Cremanthodium nobile (Franch.) Diels ex H.Lév. in having elliptic-obovate basal leaves, solitary, nodding capitula and hemispheric involucre, but differs by densely pale yellow tomentose stem, stem leaves 5-9, 1.6-2.1 cm distant, outer phyllaries $2.3-$ $2.8 \mathrm{~mm}$ wide, inner phyllaries elliptic, 3-5 mm wide, apex acute, ray lamina creamy, oblong, $2-2.3 \mathrm{~cm}$ long, apex truncate, distinctly $3-$ dentate, ray tube $1.5-2 \mathrm{~mm}$ long, tubular florets creamy, $8-9 \mathrm{~mm}$ long and pappus $6-8 \mathrm{~mm}$ long.
\end{abstract}

Keywords: Alpine, Cremanthodium nobile, Himalaya, novelty, Penga-Teng Tso Lake, Tawang District

\section{INTRODUCTION}

Cremanthodium Benth. (Asteraceae, Senecioneae) is an alpine genus distributed in the Sino-Himalayan region with a total of 78 recognized species (POWO 2019). Around half of the species are endemic to China (Wang et al. 2015). In India, it is represented by 16 species and 1 subspecies (Hajra et al. 1995; Karthikeyan et al. 2009). While working on the floristic diversity of Eastern Himalayan state Arunachal Pradesh, India (Borah et al. 2019; 2020a, b, c, d, e, f), an unidentifiable and remarkable species of Cremanthodium was collected and photographed from alpine region of Tawang District at $4100 \mathrm{~m}$ altitude in August 2017. Detailed study of Cremanthodium species of India and adjoining countries, including protologues, type specimens, other herbarium specimens and relevant taxonomic literature (Good 1929; Hajra et al. 1995; Liu and Illarionova 2011; Wang et al. 2015; 2016a, b, c, d, e, f; 2017a, b; 2018a, b; 2019; Chen and Xu 2016; Fei et al. 2019) proved this to be a new species hitherto unknown to science, which is described here as a novelty. This new species was collected again from the same locality in September 2020.

\section{MATERIAL AND METHODS}

The new species of Cremanthodium was collected from Arunachal Pradesh, eastern Himalayan state of India during plant collection trip in the year 2017 and 2020. This species was growing along the banks of Penga-Teng Tso Lake, Tawang District at $4100 \mathrm{~m}$ altitude. The collected specimens was processed using standard herbarium methods and voucher type specimens were deposited in CAL and ASSAM. Morphological observations and measurements were made on both freshly collected and dried specimens. The micromorphological characters were studied with a stereomicroscope and was compared with the protologues of reported Cremanthodium species of India and adjoining countries and digital images of type specimens housed at different herbaria, as well as actual herbarium sheets housed at ASSAM, BSD, and CAL. The number of mature individuals of the new species in the type locality was also recorded for the conservation status as per IUCN (2019). The new species Cremanthodium indica D.Borah, R.Kr.Singh \& Thungon is allied to Cremanthodium nobile (Franch.) Diels ex H.Lév. in having elliptic-obovate basal leaves, solitary, nodding capitula and hemispheric involucre, but differs in vegetative and floral characters as mentioned in diagnosis.

\section{RESULTS AND DISCUSSION}

\section{Taxonomic treatment}

Cremanthodium indica D.Borah, R.Kr.Singh \& Thungon, sp. nov. (Figure 1-3)

Type: India, Arunachal Pradesh, Tawang District, Penga-Teng Tso Lake, $4100 \mathrm{~m}, 24$ August 2017, L.T. Thungon \& D. Borah 98651 (holotype CAL; isotypes ASSAM).

Diagnosis: The new species superficially resembles Cremanthodium nobile (Franch.) Diels ex H.Lév. in having elliptic-obovate basal leaves, solitary, nodding capitula and 
hemispheric involucre, but differs by densely pale yellow tomentose stem (versus densely purplish-black pilose), stem leaves 5-9, 1.6-2.1 cm distant (versus 2-5, 4.2-7.5 $\mathrm{cm}$ ), outer phyllaries $2.3-2.8 \mathrm{~mm}$ wide (versus $3-4 \mathrm{~mm}$ ), inner phyllaries elliptic, 3-5 mm wide, apex acute (versus broadly oblong, 5-8 $\mathrm{mm}$, acuminate), ray lamina creamy, oblong, 2-2.3 cm long, apex truncate, distinctly 3-dentate (versus bright yellow, narrowly lanceolate or narrowly elliptic, $2.5-3.5 \mathrm{~cm}$, acuminate or acute, shallowly 3denticulate), ray tube $1.5-2 \mathrm{~mm}$ long (versus $3-3.5 \mathrm{~mm}$ ), tubular florets creamy, $8-9 \mathrm{~mm}$ long (versus bright yellow, 5-6 mm) and pappus 6-8 $\mathrm{mm}$ long (versus $3.5-4 \mathrm{~mm}$ ).

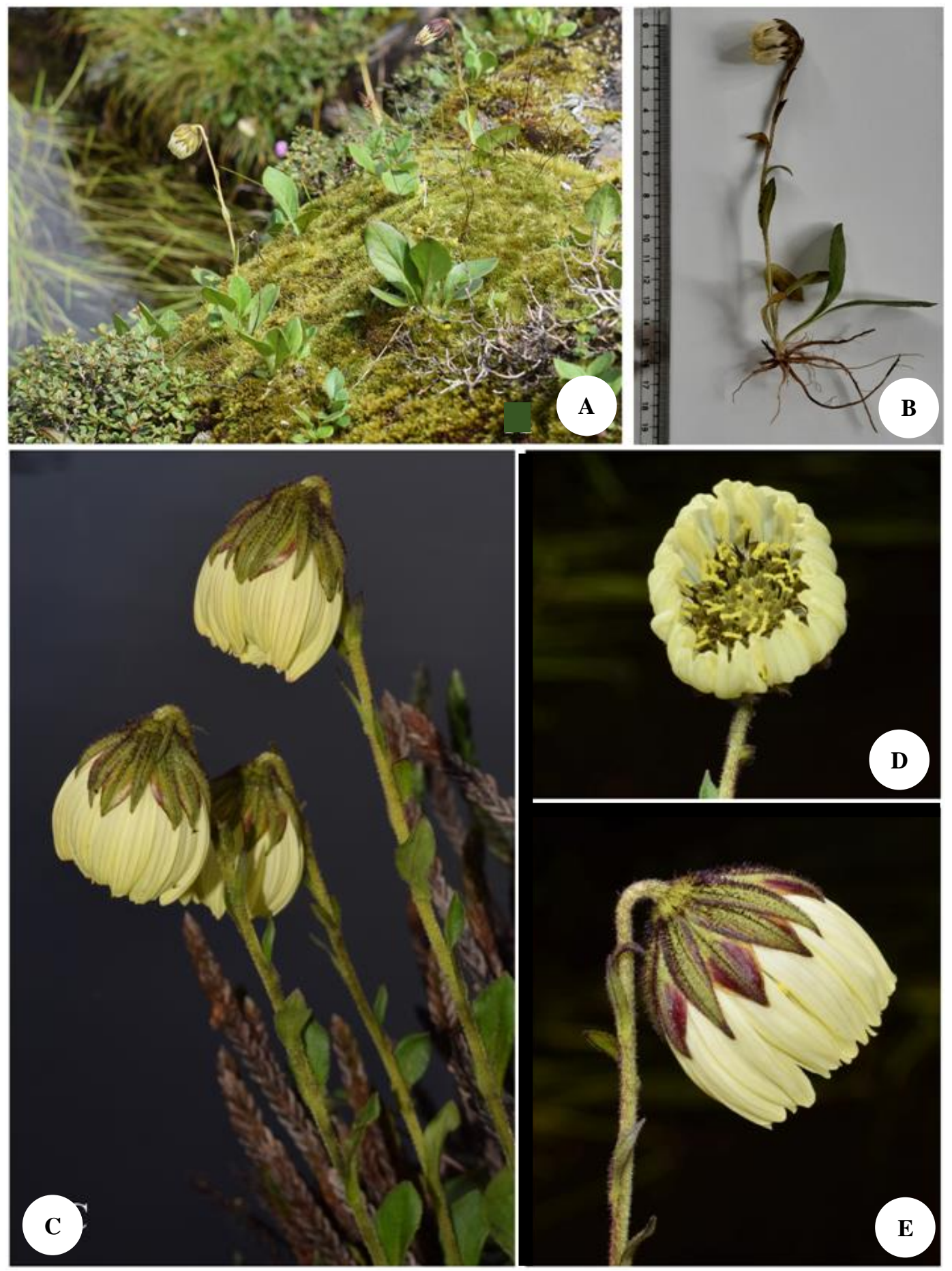

Figure 1. Cremanthodium indica D.Borah, R.Kr. Singh \& Thungon. A. Hanitat, B. Habit, C. Capitula, D. Front view of Capitula, E. Back view of Capitula 

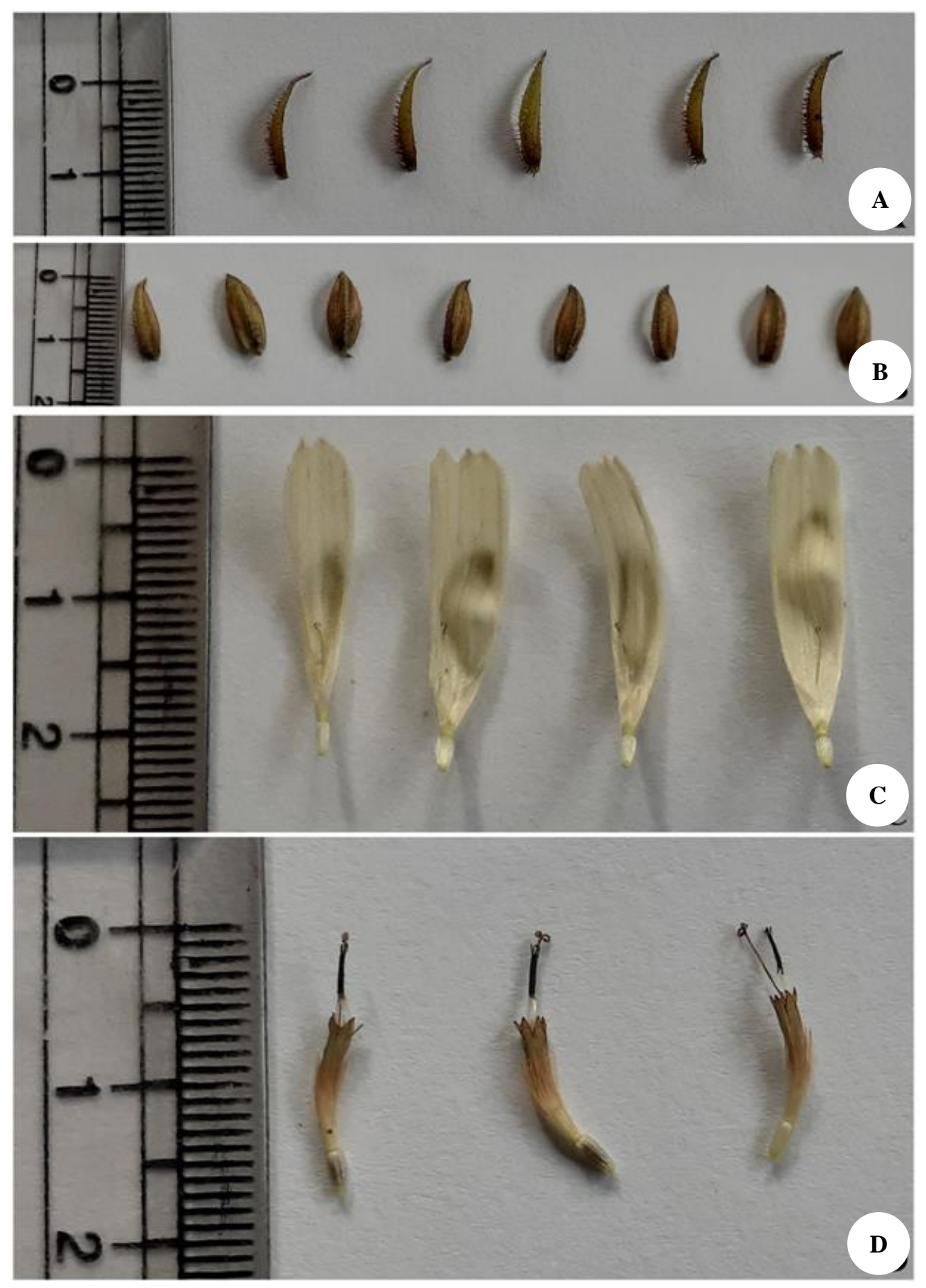

Figure 2. Cremanthodium indica. A. Outer phyllaries, B. Inner phyllaries, C. Ray florets, D. Tubular florets.

Description: Perennial herb, $16-24 \mathrm{~cm}$ tall. Roots numerous, stout, fleshy; rootlets fibrous. Stem solitary, erect, $4-5 \mathrm{~mm}$ in diameter, densely pale yellow tomentose throughout. Basal leaves petiolate; petioles $1.5-4.5 \mathrm{~cm}$ long, pale yellow pubescent, winged; wings entire, margins ciliate; leaf blades elliptic-obovate, 2-6 $\times 1-3 \mathrm{~cm}$, apex acute-obtuse or rounded, base attenuate, margins ciliate, entire or shallowly crenate, adaxially glabrous, abaxially pubescent on lateral veins; lateral veins 5-6 pairs. Stem leaves 5-9, sessile; the lowest one like basal leaf, base amplexicaul; the middle and distal ones smaller, lanceolate, margin entire, apex acute. Capitula solitary, nodding. Involucre hemispheric, $1.5-1.7 \times 2.5-3.3 \mathrm{~cm}$, outside purplish pubescent; phyllaries $12-14$ in 2 rows; outer phyllaries lanceolate, $12-15 \times 2.3-2.8 \mathrm{~mm}$, light green with purplish tinge, purplish pubescent, margins purplish ciliate, apex acuminate; inner phyllaries elliptic, $12-14 \times 3-5 \mathrm{~mm}$, light green with purplish tinge, purplish pubescent, margins purplish ciliate, apex acuminate. Ray florets creamy, 12 14; lamina oblong, $2-2.3 \times 0.5-\Gamma^{-}-\mathrm{m}$, apex truncate, distinctly 3-dentate; tube $1.5-2 \mathrm{mı} \mathbf{E}$ g. Tubular florets numerous, creamy, $8-9 \mathrm{~mm}$ long; tupe $2-2.5 \mathrm{~mm}$ long; 
limb 6-6.5 mm long; style 8-9 mm long; style branches creamy. Achenes obovoid, 2.5-3.5 mm long.Pappus creamy or pale white, $6-8 \mathrm{~mm}$ long.

Phenology: Flowering from July to August and fruiting from August to September.

Distribution: The new species is apparently endemic to Tawang District of Arunachal Pradesh state, India.
Paratypes: India, Arunachal Pradesh, Tawang District, Penga-Teng Tso Lake, $4100 \mathrm{~m}$, 5 September 2020, L.T. Thungon \& D. Borah 1784 (ASSAM).

Etymology: The specific epithet 'indica' refers to the country of origin India.

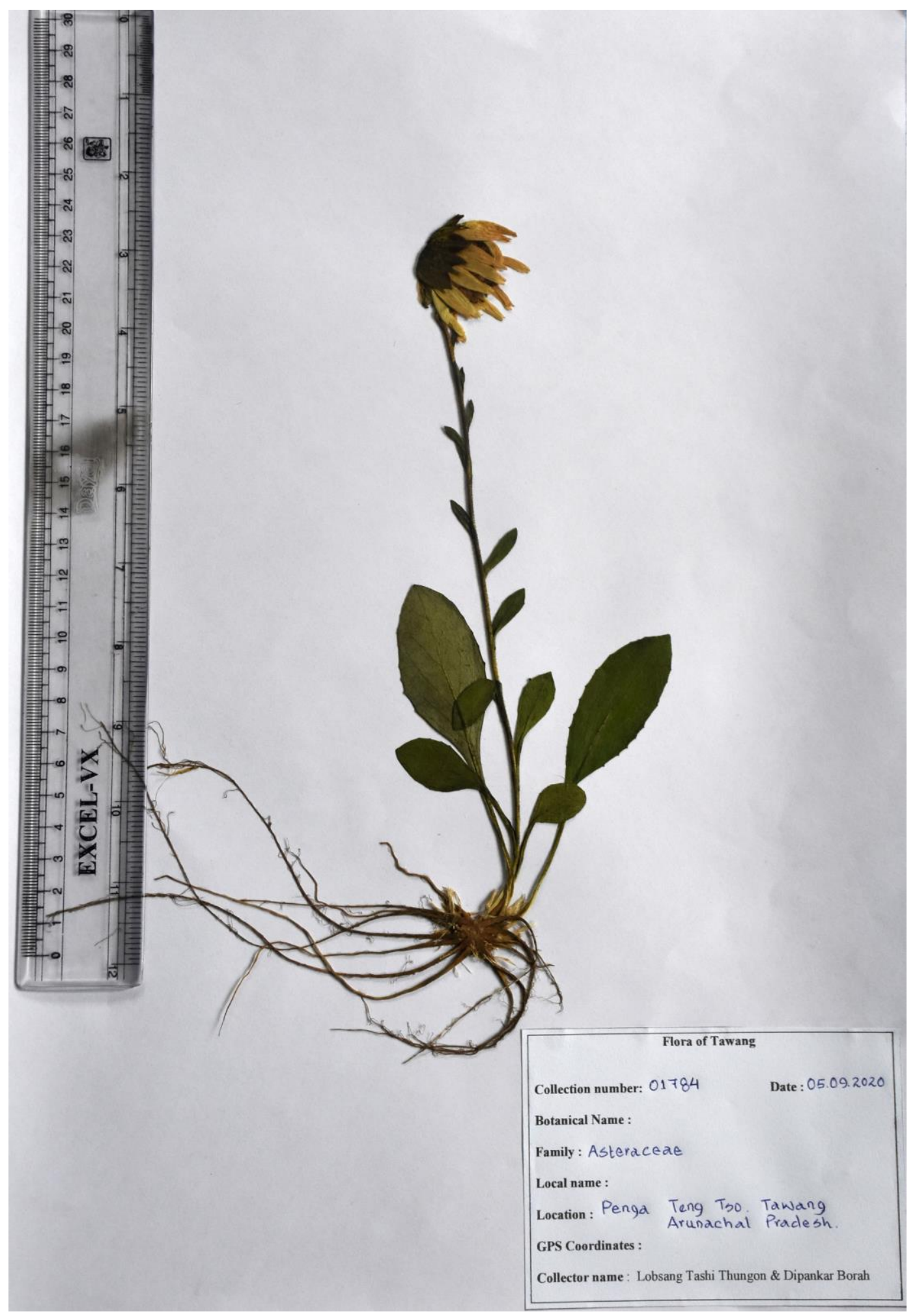

Figure 3. Herbarium specimen of Cremanthodium indica 
Habitat: Cremanthodium indica grows in boggy soil among mosses along the banks of alpine Lake in association with Bergenia ciliata (Haw.) Sternb., Bistorta vivipara (L.) Delarbre, Cirsium eriophoroides (Hook.f.) Petr., Cyananthus pedunculatus C.B.Clarke, Jacobaea raphanifolia (Wall. ex DC.) B.Nord., Pedicularis spp., Saxifraga hispidula D.Don, Swertia spp., grasses and sedges. Apart from Cremanthodium indica, other species of this genus recorded from this area are Cremanthodium conaense S.W.Liu, Cremanthodium oblanciligulatum L.Wang, C.Ren \& Q.E.Yang (ined., in press) and Cremanthodium palmatum Benth.

Conservation status: The new species Cremanthodium indica is known from type locality, Penga-Teng Tso Lake, Tawang District, Arunachal Pradesh, India. During botanical explorations trips in the year 2017 and 2020, about 270 mature individuals were recorded. Extent of occurrence is about $3 \mathrm{~km}^{2}$ and area of occupancy is about 1 $\mathrm{km}^{2}$. Natural disasters and anthropogenic threats have been noticed for this species around the lake. Based on its limited range distribution and number of mature individuals, it is provisionally assessed as critically endangered according to the criteria B1 and B2 of the IUCN (2019) guidelines.

\section{ACKNOWLEDGEMENTS}

We are grateful to Arunachal Pradesh State Forest Department for providing logistic supports during field explorations and Dr. Magnus Liden, Uppsala University, Sweden for his comments on the identity of the species. The second author is thankful to the Director, Botanical Survey of India, Kolkata and Head of Office, Botanical Survey of India, Southern Regional Centre, Coimbatore for facilities.

\section{REFERENCES}

Borah D, Das AP, Tangjang S, Wangpan T. 2019. Flowering plant diversity in the alpine regions of Eastern Himalaya. In: Patra JK, Das G, Kumar S, Thatoi H (eds.). Ethnopharmacology and biodiversity of medicinal plants. Apple academic press, Palm Bay, Florida, USA.

Borah D, Gap N, Singh RK. 2020a. Pedicularis khoiyangi (Orobanchaceae), a new species from the Eastern Himalaya, India. Phytotaxa 430: 287-293.

Borah D, Singh RK, Garg A. 2020b. New records of four Pedicularis species (Orobanchaceae) for the flora of Arunachal Pradesh state, India and two new synonyms for $P$. pantlingii. NeBio 11: 180-186.

Borah D, Singh RK, Garg A. 2020c. Rediscovery of Pedicularis denudata (Orobanchaceae), a little known, rare herb after 135 years from India. Phytotaxa 461: 136-138.

Borah D, Singh RK, Mipun P, Narah D. 2020d. Rediscovery of Pseudobartsia glandulosa (Orobanchaceae), a little known, critically endangered herb after 179 years from India, and first report from Eastern Himalayan state Arunachal Pradesh. Phytotaxa 451: 97-102.

Borah D, Singh RK,Taram M, Das AP. 2020f. Boeica arunachalensis (Gesneriaceae), a new species from Indian Eastern Himalaya and typification of five names in Boeica. Indian For 146: 871-874.

Borah D, Singh RK, Taram M. 2020e. Pseuderanthemum arunachalense, a new species from eastern Himalaya, India and typification of some names in Pseuderanthemum (Acanthaceae). Indian For 146: 660-664.

Chen YS, Xu LS. 2016. The identity of Cremanthodium acernuum and $C$. smithianum (Asteraceae). Phytotaxa 278: 65-68.

Fei WQ, Zhang Y, Wang L. 2019. Cremanthodium magnificum (Asteraceae, Senecioneae), a new species from northern Myanmar. Phytotaxa 409: 12-18.

Good RD. 1929. The taxonomy and geography of the Sino Himalayan genus Cremanthodium Benth. J. Linn. Soc Bot 48: 259-316.

Hajra PK, Rao RR, Singh DK, Uniyal BP. 1995. Flora of India, Asteraceae (Inuleae-Vernonieae), Vol. 13. Botanical Survey of India, Calcutta.

IUCN. 2019: Guidelines for using the IUCN Red List categories and criteria, version 14. Prepared by the Standards and Petitions Committee.

http://www.iucnredlist.org/documents/RedListGuidelines.pdf

Karthikeyan S, Sanjappa M, Moorthy S. 2009. Flowering plants of India, dicotyledons (Acanthaceae - Avicenniaceae), Vol. 1. Botanical Survey of India, Kolkata.

Liu SW, Illarionova ID. 2011. Cremanthodium Bentham. In: Wu ZY, Raven PH (eds) Flora of China, Vol. 20-21. Science Press, Beijing \& Missouri Botanical Garden Press, St. Louis.

POWO. 2021. Plants of the World Online. Royal Botanic Gardens, Kew. http://www.plantsoftheworldonline.org/

Wang L, Ren C, Yang Q. 2015. Cremanthodium wumengshanicum (Asteraceae, Senecioneae), a new species from Yunnan, China. Phytotaxa 238: 265-270.

Wang L, Ren C, Yang Q. 2016a. Cremanthodium botryocephalum and $C$. spathulifolium are both merged with Ligularia lagotis (Asteraceae, Senecioneae). Phytotaxa 247: 274-280.

Wang L, Ren C, Yang Q. 2016b. A new combination in Cremanthodium (Asteraceae, Senecioneae) from Sichuan, China. Phytotaxa 252: 137142.

Wang L, Ren C, Yang Q. 2016c. Reinstatement of the Chinese species Cremanthodium gypsophilum (Asteraceae, Senecioneae). Phytotaxa 284: 131-136.

Wang L, Ren C, Yang Q. 2016d. Cremanthodium liangshanicum (Asteraceae, Senecioneae), a new species from southwestern Sichuan, China. Phytotaxa 286: 161-168.

Wang L, Ren C, Yang Q. 2016e. Cremanthodium nobile var. yanyuanense (Asteraceae, Senecioneae), a new epappose taxon from southwestern Sichuan, China. Phytotaxa 286: 198-202.

Wang L, Ren C, Yang Q. 2016f. Clarification of the confusing identity of Cremanthodium atrocapitatum (Asteraceae, Senecioneae), with a new combination and description of a new species in the genus. Phytotaxa 288: 1-18.

Wang L, Ren C, Yang Q. 2017a. The identity of Cremanthodium citriflorum (Asteraceae, Senecioneae). Phytotaxa 297: 42-52.

Wang L, Ren C, Yang Q. 2017b. Cremanthodium lingulatum (Asteraceae, Senecioneae) is merged with C. pseudo-oblongatum. Phytotaxa 311: 57-66.

Wang L, Ren C, Yang Q. 2018a. Rediscovery of Cremanthodium principis (Asteraceae, Senecioneae) in northwestern Yunnan, China. Phytotaxa 343: 277-282.

Wang L, Ren C, Yang Q. 2018b. Two new species in Cremanthodium (Asteraceae, Senecioneae) from China. Phytotaxa 360: 201-219.

Wang L, Ren C, Yang Q. 2019. Cremanthodium weixiense (Asteraceae, Senecioneae), a new species from northwestern Yunnan, China. Nordic J Bot 2019: e02242. DOI: 10.1111/njb.02242 